\title{
Ayat Toleransi Dalam Al-qur'an; Tinjauan Tafsir Al-Qurthubi
}

\author{
Mufidatul Bariyah \\ Institut Pesantren KH. Abdul Chalim Mojokerto \\ fizma danrajh@gmail.com
}

\begin{abstract}
;
Embodies the Attitude of religious tolerance in Indonesia is not by way of saying that all religions that exist in the community is the same, because in fact we can see, every religion is different, although it has some aspects in common. For example in the case of the core teachings that together teach kindness to its adherents. The tolerant attitude that must be applied in Indonesia is a necessity of society in accepting the existence of differences that is certainly on the everyday life with open arms. The reception of this kind is not a union arbitrarily to all religions, but as an effort to cultivate and develop an attitude of mutual acceptance in the form of respect for all the differences that exist in the community. According to the teachings of Islam, tolerance is not only in the middle against fellow human beings, but also against god's creation that other, better for the environment, the universe, and the beast, the manifestation of religious tolerance can be interpreted as an attitude of individuals or groups who accept the existence of differences arising from a belief to a different religion. Through the process of appreciating and accepting the existence of different faiths, but in these social relationships, not infrequently we find the presence of conflict as a parasite that hinder the realization of social normative, it is due to adannya goal difference in the life of each, either group or individual. See religion evolve into the impression that raises issues that are emotional shell so blind with understanding tolerance. Within the scope of the religion of Islam, Alquran in outline has been talking about the relation of creatures with God along with the Universe and its contents, Al-quran, also examine about the discussion of humanitarian issues that confront him in this life.
\end{abstract}

Key word: Tolerance, Tafsir Al- Qurthubi, Context of Indonesia

\begin{abstract}
Abstrak
Mewujudkan Sikap toleransi agama di Indonesia bukan dengan cara mengatakan bahwa semua agama yang ada pada masyarakat adalah sama, sebab pada fakta yang bisa kita lihat, setiap agama memang berbeda, walau memiliki beberapa aspek kesamaan. Misalnya dalam hal inti ajaran yang sama-sama mengajarkan kebaikan kepada penganutnya. Sikap toleran yang harus di terapkan di Indonesia adalah keharusan masyakat
\end{abstract}


dalam menerima adanya perbedaan yang bersifat pasti pada kehidupan sehari-hari dengan tangan terbuka. Penerimaan semacam ini bukan merupakan penyatuan yang semena-mena kepada semua agama yang ada, akan tetapi sebagai upaya untuk menumbuhkan dan mengembangkan sikap saling menerima dalam wujud menghormati segala perbedaan yang ada pada masyarakat. Menurut ajaran agama Islam, toleransi bukan saja di realisasikan terhadap sesama manusia, akan tetapi juga terhadap ciptaan tuhan yang lainnya, baik terhadap lingkungan hidup, Alam semesta, dan binatang, manifestasi toleransi beragama dapat diartikan suatu sikap individu atau kelompok yang menerima adanya perbedaan yang timbul dari seorang yang berkeyakinan kepada agama yang berbeda. Melalui adanya proses menghargai dan menerima adanya keyakinan yang berbeda-beda, namun dalam hubungan sosial ini, tidak jarang kita temukan adanya konflik sebagai benalu yang menghambat terwujudnya sosial yang normatif, hal ini disebabkan karena adannya perbedaan tujuan dalam kehidupan masing-masing, baik kelompok ataupun individu. Melihat agama berkembang menjadi kesan yang menimbulkan isu-isu yang bersifat emosianal sehingga buta dengan pemahaman toleransi yang ada. Dalam ruang lingkup agama Islam, Al-quran secara garis besar telah membicarakan tentang relasi makhluk dengan Tuhan beserta alam Semesta dan isinya, Al-quran juga mengkaji tentang pembahasan masalah kemanusiaan yang di hadapinya dalam kehidupan ini.

Kata kunci: Toleransi, Tafsir Al- Qhurtubi, Konteks Indonesia

\section{Pendahuluan}

Manusia di ciptakan Tuhan sebagai makhluk yang saling membutuhkan, telah mejadi hukum alam bahwa manusia terlahir di muka bumi ini sebagai makhluk sosial, untuk menjadi manusia yang sempurna, manusia tidak bisa terlepas dari intraksi sosial kepada sesamanya, sehingga terciptalah suatu hubungan normatif yang terlahir sebagai nilai- nilai kedamaian, ketentraman dan kerukunan dalam masyarakat. Manusia membutuhkan peran orang lain dalam melengakapi kebutuhannya, baik dari segi material ataupun spritual. Namun dalam hubungan sosial ini, tidak jarang kita temukan adanya konflik yang berperan sebagai benalu yang menghambat bagi terwujudnya kehidupan sosial yang normatif, hal semacam ini disebabkan karena adannya perbedaan tujuan atau persepsi dalam kehidupan masing-masing, baik kelompok ataupun individu. ${ }^{17}$

Berkaitan dengan beberapa perbedaan di masyarakat, seringkali agama menjadi peran utama yang memicu adanya konflik sosial di masyarakat, sehingga pandangan orang terhadap nilai moral agama tidak terlihat harmonis lagi di setiap antar agama, agama yang di anggap pedoman yang suci bagi penganutnya kemudian berkembang menjadi kesan yang

17 Toto Suryana, "Konsep dan Aktulisasi Kerukunan Ummat Beragama”. Jurnal Pendidikan Agama Islam Ta'lim Vol. 9 No. 2 - 2011, hlm 127 
menimbulkan isu-isu yang bersifat emosianal. ${ }^{18}$ Dalam kasus tertentu, seperti yang telah terjadi pada toleransi islam ini, konflik yang menunjukan rasa sensitifnya terhadap permasalahan akut yang di hadapi oleh kelompok umat islam terkini: faham radikal, teror dan kekerasan bermotif agama yang di sebabkan oleh kelompok-kelompok ekstrimis yang menganggap paling benar dan paling salah dalam keislamannya ${ }^{19}$

Beberapa kasus yang terjadi ini disebabkan karena agama selalu di terima dan di dalami secara subjektif. Akibatnya, manusia sering kali menafsirkan agama sesuai dengan pengalaman dan penghayatannya masing-masing terhadap agama yang dianutnya, sehingga menimbulkan pendapat dan pemahaman yang berbeda-beda dari pengalaman yang beragam, tergantung kepada siapa yang menafsirkannya. ${ }^{20}$

Hal semacam inilah yang telah banyak terjadi di Indonesia, bangsa Indonesia terkenal sebagai bangsa yang mempunyai kerukunan yang tinggi, namun kenyataan yang terjadi memperlihatkan bahwa radikalisme mulai menjalar dan berkembang di Indonesia, namun tidak bisa di pungkiri bahwa pemahaman agama merupakan penyebabnya. Terjadinya berbagai konflik semacam ini seharusnya menjadi peran penting dalam menyadarkan semua masyarakat beragama untuk mengembalikan makna toleransi yang ada pada negara Indonesia, dengan melakukan berbagai macam usaha baik pemikiran dan aksi nyata. Sebagaimana pendapat Nurcholis Madjid tentang pentingnya peranan Toleransi dalam konteks kehidupan Masyarakat Indonesia, bahwa Indonesia dengan tingkat pluralisme yang tinggi memerlukan usaha yang seimbang,serius, dan kreatif dalam pengolahannya.

Dalam ruang lingkup umat Islam, Al-quran menjadi tuntunan bagi penganutnya dan banyak menbicarakan Realitas tertinggi yang memperlihatkan secara filosofis, tidak menerima kebenaran bagi selainnya. Akan tetapi secara sosiologis, umat Islam juga sangat toleran menerima adanya keyakinan yang berbeda. ${ }^{21} \mathrm{Al}$-quran sesuai konsensus umat Islam, merupakan landasan utama yang menempati posisi paling sentral bagi semua disiplin ilmu keislaman. Alquran di samping sebagai "hudan" atau petunjuk bagi ummat manusia, juga menjadi "Bayyinat min al huda" yang berarti penyelaras bagi petunjuk-petunjuk tersebut, yang berkaitan dengan perincian- perincian hukum syariat. ${ }^{22}$

Bagi umat islam Al-quran adalah petunjuk dari Allah untuk hambanNya, yang jika dipelajari akan membantu manusia untuk menemukan nilai-nilai kehidupan serta dapat dijadikan pedoman serta sandaran untuk menyelesaikan berbagai konflik dalam hidup. Alquran apabila dihayati, diamalkan dan di jadikan pedoman akan menjadikan pikiran, rasa

18 Muhammad Yasir, "Makna Toleransi Dalam Al-quran" Jurnal Ushuluddin Vol. XXI No. 2, Juli 2014, hlm 170

19 M. Quraisy Shihab, Membumikan Alquran Fungsi dan Pesan Wahyu Dalam Kehidupan Masyarakat, ( Bandung: Mizan, 1992 ) hlm. 22

${ }^{20}$ Dr.Ngainun Naim, Islam Dan Pluralisme Agama Dinamika Perebutan Makna (Yogyakarta: Aura Pustaka, 2014), hlm. 1

21 Atang Abd Hakim, Metodologi Studi Islam, (Bandung: Pustaka Setia, 2008) hlm. 56

${ }_{22}$ M.Quraisy Shihab, Tafsir Al-Misbah, Pesan, Kesan dan Keserasian Al-quran, Jakarta: Lentera hati, Vol I, hlm. 487 
dan karsa yang mengarahkan kita pada realitas keimanan, tentunnya yang dibutuhkan bagi stabilitas hidup pribadi dan masyarakat. Munculnya perbedaan dalam masalah agama tidak menjadi penghambat dalam menciptakan hubungan baik kepada antar ummat beragama. ${ }^{23}$

Dalam kodisi seperti ini, maka Tafsir ayat-ayat Al-quran versi tafsir kitab Al-Qurthubi ini menjadi penting untuk di kaji, sebagai salah satu bentuk standarisasi penafsiran yang terkesan literal, seperti yang di katakan dan oleh kalangan fundamentalis. ${ }^{24}$

\section{Pengertian Toleransi}

Toleransi menurut Abdul Malik Salman, berasal dari bahasa latin yang memiliki arti berusaha tetap bertahan hidup dan dapat berintraksi dengan sesuatu walau sesuatu tersebut sesungguhnya tidak ia sukai. ${ }^{25}$

Berdasarkan pemikiran Alport menyatakan, bahwa istilah toleransi diartikan sebagai suatu sikap yang bersahabat, penuh keparcayaan diri terhadap orang lain tampa memperdulikan dari mana kelompok itu berasal. Perwujudan makna toleransi adalah kemampuan sikap untuk menerima orang lain. Sedangkan menurut pandangan Abdullah bin Nuh (Hasyim 1979) di dalam kamus barunya menejelaskan, makna toleransi dari kata tolerare yang memiiki arti menahan diri, memiliki sifat sabar, tenggang rasa dan membiarkan seorang untuk memiliki pendapat yang berbeda, serta menghargai terhadap seorang yang memiliki keyakinan berbeda dalam beragama. ${ }^{26}$

Pengertian toleransi lainnya dapat di artikan, mempersilahkan terbentuknya sistem yang menjamin unsur-unsur pribadi atau minoritas yang ada pada masyarakat dengan menghormati terhadap agama lain, baik moralitas dan lembaga lembaga mereka, serta menghormati perbedaan-perdaan yang terjadi di lingkungannya, tanpa harus berselisih dan memandang sebelah mata hanya karena berbeda keyakinan dan Agama. ${ }^{27}$

Dalam bahasa Arab kata yang serupa dengan makna toleransi adalah Ikhtimal dan Tasammuh, yang memiliki makna sikap membiarkan, teposelero dan lapang dada. Akan tetapi Al-quran tidak pernah menyebutkan kata tasamuh secara tersurat di dalamnya, namun secara eksplisit Al-quran menjelaskan berbagai konsep toleransi dengan batasanbatasannya secara jelas. Oleh karena itu, ayat-ayat yang bersangkutan dengan makna

\footnotetext{
23 M.Quraisy Shihab, Membumikan Alquran Fungsi dan Pesan Wahyu Dalam Kehidupan Masyarakat, (Bandung: Mizan, 2002) hlm. 95

${ }^{24}$ Suroso Adi, "Menejemen Alam: Sumber Pendidikan Nilai, (Bandung : Mughni Sejahtera, 2006) hlm.46

25 Abdul Malik Salman, al-Tasamub Tijah al-Aqoliyyat ka Dharuratin li al-Nabdhah, (Kairo: The International Instutite Of Islamic Thought, 1993) hlm. 2. M Thoriqul Huda dan Nur Hidayati,'Peran Komisi Hubungan Antar Umat Beragama Gereja Katolik dalam Membangun Dialog", Religi; Jurnal Studi Agama-Agama, Vol 14 No. 2 2019, 194-216.

${ }^{26}$ Rangga Prawira, Skripsi: "Hubungan Antara Makna Hidup Dengan Toleransi Beragama Pada Jamaah Salafy di Bekasi” ( Jakarta: UIN Syarif Hidatullah, 2010 ) hlm. 13

${ }_{27}$ Alwi shihab, Islam Inklusif, Menuju Sikap Terbuka dalam Beragama (Bandung: Mizan, 1997) hlm. 43. M Thoriqul Huda,'Urgensi Toleransi Antar Agama dalam Prespektif Tafsir al-Sya'rawi”, Tarbiya Islamia: Jurnal Pendidikan dan Keislaman, Vol 8 No. 1 2019, 44-60.
} 
toleransi beragama dapat di jadikan rujukan utama dalam implementasi dalam kehidupan bermasyarakat $^{28}$

Menurut ajaran agama Islam, toleransi bukan saja di realisasikan terhadap sesama manusia, akan tetapi juga terhadap ciptaan tuhan yang lainnya,baik terhadap lingkungan hidup, Alam semesta, dan binatang. ${ }^{29}$

Dari pernyataan di atas, dapat disimpulkan bahwa manifestasi toleransi beragama dapat diartikan suatu sikap individu atau kelompok yang menerima adanya perbedaan yang timbul dari seorang yang berkeyakinan kepada agama yang berbeda. Melalui adanya proses menghormati, menghargai, dan menerima atas adanya keyakinan yang berbeda-beda.

Terdapat dua tipe toleransi beragama yakni yang

1. toleransi beragama bersifat pasif, yakni sikap menerima perbedaan sebagai sesuatu yang bersifat faktual.

2. Sedangkan yang kedua toleransi beragama bersifat aktif, yakni toleransi yang melibatkan dirinya dengan orang lain dalam ruang lingkup perbedaan dan keagamaan, seperti yang telah di ajarkan oleh setiap agama.

pada hakikatnya toleransi beragama adalah hidup bersama secara damai dan saling memancarkan sikap mengahargai di tengah keragaman. ${ }^{30}$

Untuk mewujudkan adanya sikap toleran dalam beragama bukan dengan cara mengatakan bahwa semua agama yang ada pada masyarakat adalah sama, sebab pada fakta yang bisa kita lihat, setiap agama memang berbeda, walau memiliki beberapa aspek kesamaan. Misalnya dalam hal inti ajaran yang sama-sama mengajarkan kebaikan kepada penganutnya. Dapat ditekankan bahwa sikap toleran adalah jika seorang mampu menerima adanya perbedaan yang bersifat pasti pada kehidupan sehari- hari. Penerimaan semacam ini bukan merupakan penyatuan yang membabi-buta semua agama yang ada, akan tetapi sebagai upaya untuk menumbuhkan dan mengembangkan sikap saling menerima dalam wujud menghormati segala perbedaan yang ada pada masyarakat. ${ }^{31}$

Dalam ruang lingkup agama Islam, Al-quran secara garis besar selain membicarakan tentang relasi makhluk dengan Tuhan (Ikhwal ketuhanan) beserta alam Semesta dan isinya, juga mengkaji tentang pembahasan masalah kemanusiaan yang di hadapinya dalam kehidupan. ${ }^{32}$

\footnotetext{
${ }_{28}$ Mujetaba Mustafa, "Toleransi Beragama dalam Perspektif Al-quran” TASAMUH, Vol. 7, No. 1, April 2015, hlm.5

29 Asep Syaefullah, Merukunkan Umat Beragama (studi pemikiran tarmidzi taher Tentang Kerukunan Umat bergama), (Jakarta Selatan: Grafindo Khasanah Ilmu, 2007), hlm. 129

30 Casram, Membangun Sikap Toleransi Beragama Dalam Masyarakat Plural, Jurnal: Wawasan Jurnal Ilmiah Agama dan Sosial Budaya 1, 2.187-198 juli 2016), hlm.191. Baca juga dalam M Thoriqul Huda,"Toleransi dalam Kitab Tafsir Taisir al-Karim al-Rahman fi Tafsir al-Kalam al-Mannan", Qolamuna; Jurnal Studi Islam, Vol. 4 No, 2 2019, 249-266.

31 Ibid hlm. 95

32 Ahmad Syafi'i Ma’arif, Membumikan islam (Yogyakarta: Pustaka Pelajar, 1995), hlm. 3
} 
Pada konteks Toleransi antar umat beragama, menurut dasar islam berarti mempunyai konsep yang jelas, tidak ada pemaksaan dalam melilih agama, contoh landasan

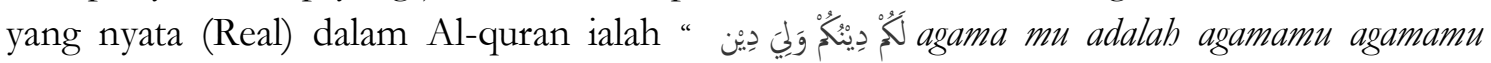
adakah agamaku", potongan ayat ini adalah salah satu contoh populer pada konteks toleransi bagi agama Islam di sinilah letak dasar Islam mengenai toleransi bergama. ${ }^{33}$

Walaupun Al-quran juga memberi penegasan di dalamnya bahwa agama Islam adalah satu-satunya agama yang di terima oleh Allah,tetapi Allah memberikan kebebasan untuk memilih dan menerima kebenaran Islam atau menolak dan meyakini Agama lain. Dengan inilah toleransi beragama dapat terwujud tanpa memaksa seorang dalam hal agama $^{34}$

\section{Ayat -ayat tentang Toleransi dalam Al-quran}

Teks Surat Al-Baqarah ayat 256

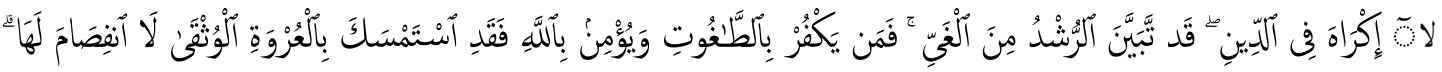

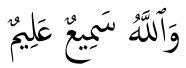

"Tidak ada paksaan untuk memasuki agama Islam Sesunggubnya telah jelas jalan yang benar daripada jalan yang sesat. Karena itu barangsiapa yang ingkar kepada Thaghut dan beriman kepada Allah, maka sesunggubnya ia telah berpegang kepada tali yang amat Kuat (Islam) yang tidak akan putus. dan Allah Maha mendengar lagi Maha Mengetabui."'35

Makna umum dari ayat ini ialah pemberitahuan kepada penganut semua agama terhadap pentingnya bertoleransi, dan ayat ini menjelaskan bahwa ummat Islam tidak melarang untuk menerapkan sikap saling berhubungan baik kepada agama lainnya. Namun di sisi lain, Islam melarang atau tidak menganjurkan untuk bersahabat dengan orang-orang yang memerangi dan memusuhi Islam serta penganutnya, karena orang-orang yang memerangi Islam harus di adili secara tegas, agar mereka mengetahui bahwa Islam adalah agama yang menjunjung tinggi sikap toleransi kepada semua agama, selama agama tersebut tidak ada unsur untuk memerangi dan mengganggu agama Islam. ${ }^{36}$

Teks surat $\mathrm{Al}$ maidah ayat 5

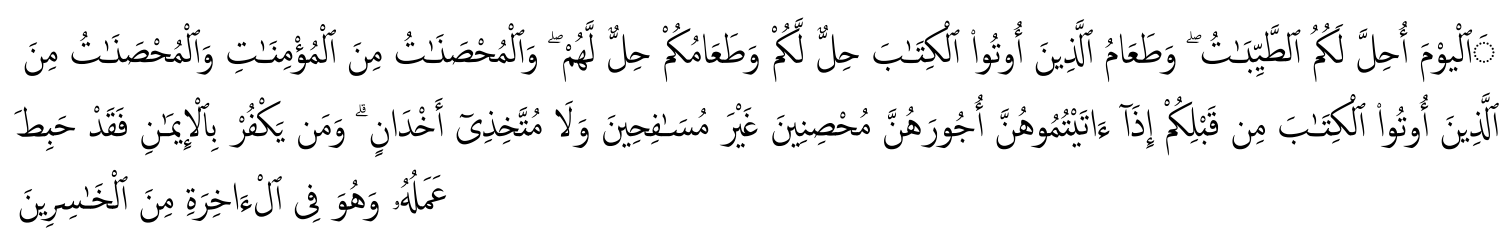

\footnotetext{
33 Adian Husaini, Hermeneutika dan Tafsir Al-quran (Jakarta: Gema insani, 2007) hlm. 14

${ }^{34}$ Dhur Anni, "Tafsir Ayat Muamalah (Toleransi Beragama)" Institute KH. AbdulChalim, hlm. 3

${ }^{35}$ CORDOBA “Internasinal Indonesia”, Tafsir Al-quran Bil Hadist, al- Baqoroh ayat.256

36 Abu bakar, "Konsep Toleransi dan Kebebasan Beragama", Toleransi: Media Komonikasi Umat Beragama, Vol. 17, No. 2 Juli-Desember 2015 hlm. 127
}

36 | Mufidatul Bariyah, -Ayat Toleransi dalam Al Qur’an; Tinjauan Tafsir Al Qurthubi 
Pada hari ini, di halalkan bagi mu segala yang baik-baik makanan (sembelihan) abli kitab itu halal bagi mu, dan makanan mu halal bagi mereka. Dan (di balalkan bagi mu menikahi) perempuanperempuan yang menjaga kehormatan di antara perempuan-perempuan yang beriman dan perempuanperempuan yang menjaga kehormatan di antara orang-orang yang di beri kitab sebelum kamu, apabila kamu membayari maskawin mereka untuk menikahi nya tidak maksud berzina dan bukan menjadikan perempuan piaraan. Barang siapa kafir setelah beriman maka sungguh, sia-sia amal mereka dan akbirat dia termasuk orang-orang yang rugi. ${ }^{37}$

Makna umum dari ayat ini menjelaskan bahwa di perbolehkannya (halal) untuk memakan makanan Sembelihan dan menikahi wanita dari golongan abli kitab, dengan demikian, maka wujud dari ayat ini akan menimbulkan rasa partisipasi sosial, sehingga tumbuh di antara mereka saling menghormati, saling bertamu, menjamu, dan saling berkunjung satu sama lain dengan dasar sikap toleransi. ${ }^{38}$

\section{Teks surat Al-kafirun 1-6}

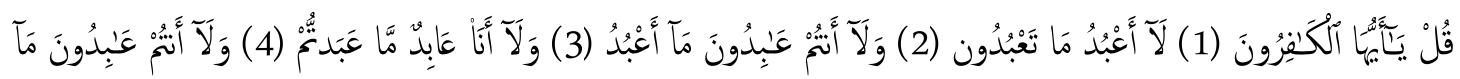

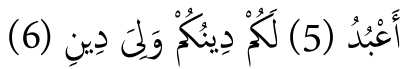

Katakanlah (Mubammad),wahai orang-orang kafir! aku tidak akan menyembah apa yang kamu sembah.dan kamu bukan penyembah. Allah yang Aku sembah.dan aku tidak. pernah menjadi penyembah apa yang kamu sembah. Dan kamu tidak. (pula) menjadi penyembah ilah yang aku sembah .untukmu agamamu,dan untukeku agamaku. ${ }^{39}$

Makna umum dari ayat ini berarti, setiap orang dengan agama yang berbeda di perkenankan untuk menerapkan atau mengamalkan setiap ajaran yang di peroleh dari masing-masing ajaran agamanya, dengan aturan-aturan yang telah ada, tanpa mengganggu hak dan kenyamanan agama lainnya. Dalam ayat ini menegaskan bahwa agama Islam menerima (mengiktiraf) dan menganggap adanya agama-agama selainnya di dunia ini sebagai sunnatullah. ${ }^{40}$

\section{Ayat-ayat Toleransi Dalam Al-qur'an persfektif Tafsir Al-Qhurtubi}

Tafsir surat al-Baqoroh

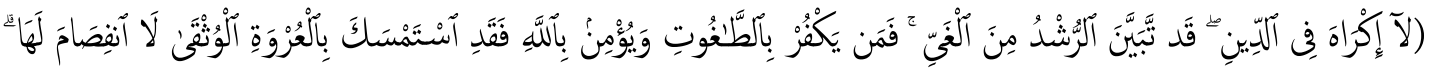

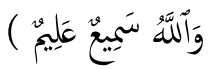

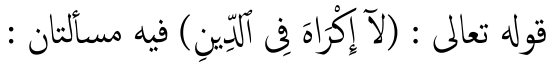

\footnotetext{
${ }^{37}$ CORDOBA “ Internasinal Indonesia”, Tafsir Al-quran Bil Hadist, al-Maidah, ayat.5

38 Ibid. hlm.98

${ }^{99}$ CORDOBA “Internasinal Indonesia”, Tafsir Al-quran Bil Hadist, Al-Kafirun ayat. 1-6

${ }^{40}$ Khadijah, "Toleransi Beragama Dan Amalannya di Malaysia" Jurnal Ushuluddin, Bil 27 (2008) 81-92, hlm. 84
} 


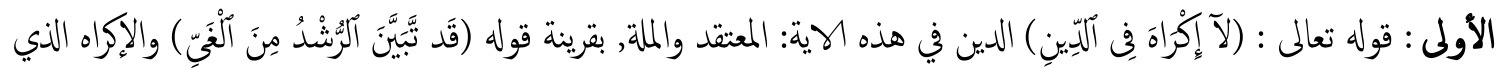

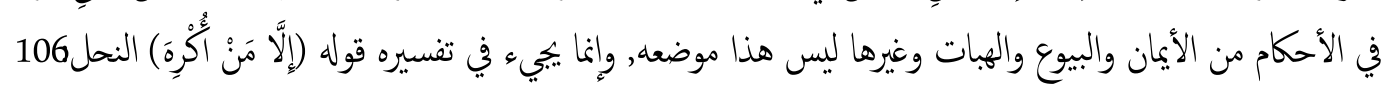

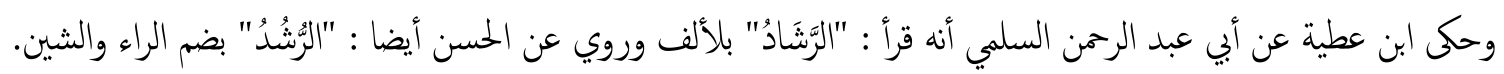

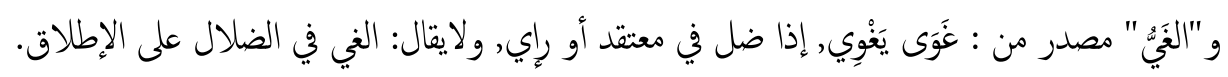

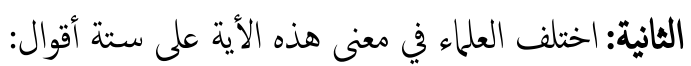

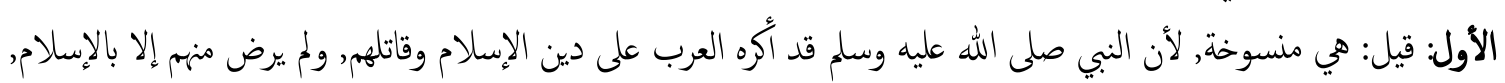

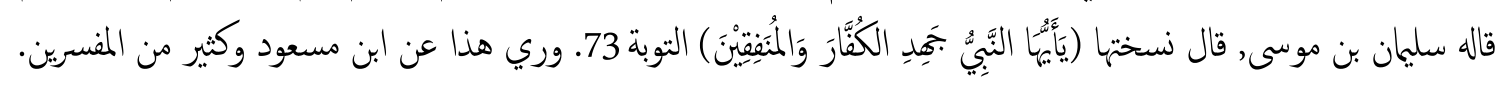

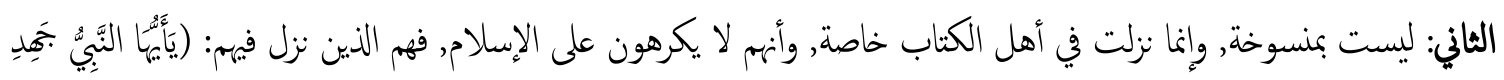
الكُفُقَرَ) ). هذا قول الشعبي وقتنادة والحسن والضحاك.

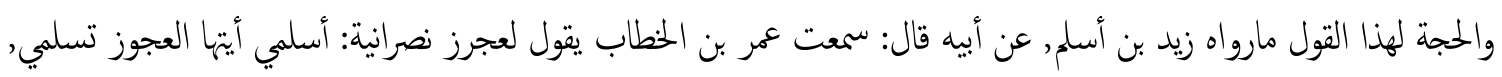

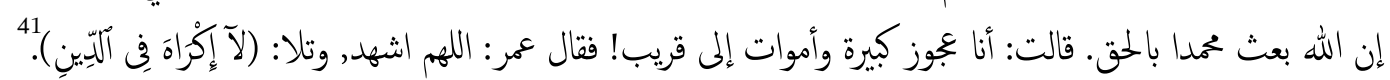
الرابع: قال السدي: نزلت الأية في رجل من الأنصار يقال له: أبو حصين, كان له ابنان, فقدم تجار من الشام إلى المدينة يحملون

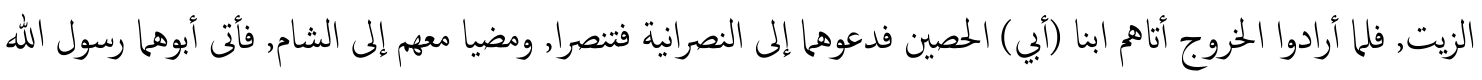

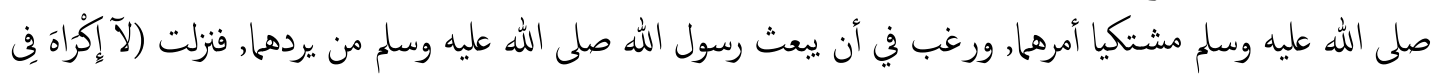

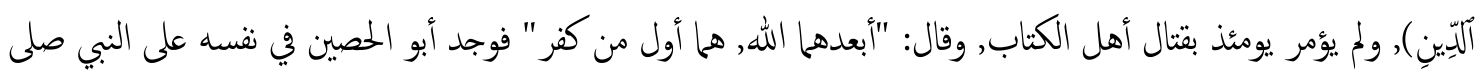

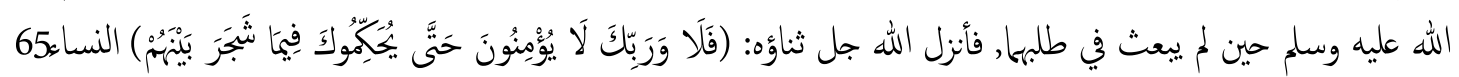

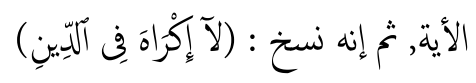

Dalam ayat ini terdapat dua permasalahan, permasalahan pertama terdapat pada ayat الاراه في الدين) yakni pada lafadz Ad-din الدين ayat ini memiliki dua makna, makna yang pertama adalah "sesuatu yang di yakini" sedangkan makna yang kedua berarti "agama". Adapun pada lafadz (لادين alasan adannya ayat الاكراه في الدين ini adalah, firman Allah ta'ala pada lanjutan ayat tersebut, yakni (قد تبين الرشد من الني), yang memiliki makna petunjuk dari kesesatan. Sedangkan pada lafadz اكراه yang terdapat pada bab hukum, aiman, buyuk, hibah (bab jual beli) bukanlah makna yang sesuai dengan ayat ini( toleransi). akan tetapi, ayat yang sesuai dengan pembahasan jual beli terdapat pada ayat الامن اكراه yang terdapat pada surah an-Nahl ayat 106 .

Dan di ceritakan juga oleh Ibnu Atiyah dari Abi Abdil Rohman, beliau membaca nya الرشاد dengan menggunakan alif setelah huruf syin dan di riwayatkan juga dari hasan

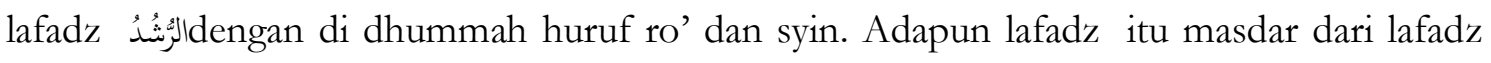
ghowa yaghwi ketika sesuatu telah kesasar dalam keyakinan atau pendapat, dan tidak bisa di

${ }^{41}$ Abi Abdillah Muhammad bin Ahmad bin Abi Bakar Al Qurtubi, Al-Jami li Ahkam Al-quran, juz 4, hal 280.

38 | Mufidatul Bariyah, -Ayat Toleransi dalam Al Qur’an; Tinjauan Tafsir Al Qurthubi 
ucapkan kesasar secara mutlak. Maksudnya Al-khoyyu itu harus tersesat dalam sebuah perkara yg di yakini.

Permasalahan yg kedua adalah adanya perbedan pendapat oleh para ulama dalam memaknai ayat ini, pendapat tersebut terbagi menjadi beberapa tanggapan di antaranya yaitu:

1. Pendapat pertama mengatakan bahwa, ayat tersebut di mansukh (di salin), karna nabi Muhammad mengajak orang-orang Arab untuk meyakini agama Islam dan memeranginya bagi orang yang melanggar aturan yang telah di sepakati sebelumnya. Dan beliau tidak ridho kepada ummatnya kecuali bergama agama Islam.

Sedangkan menurut pendapat Sulaiman bin Musa beliau berkata dengan adanya bukti ayat yang menasekh. يا يها النبي جهد الكفار والمنفقين yang terdapat pada Surat at-Taubat ayat 73. Konteks ini telah diriwayatkan juga oleh Ibnu Masud dan masih banyak dari para ulama ahli tafsir lainnya.

2. Pendapat ini mengatakan bahwa, Ayat tersebut tidak di salin atau di mansukh, karna hanya di turunkan husus pada ahli kitab dan orang-orang kafir yang tidak di paksa masuk Islam ketika sudah bayar jizyah (pajak), yang seharusnya di paksa adalah ablu ausan (orang yg menyembah berhala) sehingga mereka tidak di terima kecuali masuk Islam dan mereka adalah orang-orang yang di turuni ayat يا يها النبي جحد الكفار pendapat Syakbi, Qotadah, Hasan dan Dhohhak. adapun hujjah atau penguatan pendapat dari perkara tersebut, diriwayat kan oleh Zaid bin Aslam, berupa hadist yang diriwayatkan ayahnya, beliau berkata, "saya mendengar dari Umar bin Khatab beliau berkata kapada orang tua golongan nasrani "Masuk Islamlah wahai orang yang tuarenta Maka kamu akan selamat". Allah mengutus nabi dengan perkara yang hak. Kemudian orang tersebut berkata, "saya orang yang sudah sangat tua dan sebentar lagi saya akan mati”. Kemudian Umar mendoakan اللهم اشهيد (wahai Allah saksikanlah) dan beliau membaca ayat لا اكراه في الدين.

3. Dalam pendapat ini di riwayatkan oleh Assudiu, ia berkata, ayat ini di turunkan kepada orang laki-laki Ansor, mereka adalah Abu Husain dan dua anak laki-lakinya, kemudian ada pedagang dari Syam masuk ke kota Madinah dengan membawa minyak, ketika mereka hendak keluar dari Madinah kemudian di hampiri oleh dua anak laki-laki Abi Husain, sehingga mereka mengajak dua anak laki-laki tersebut masuk kedalam agama nasrani, maka kedua anak tersebut menjadi nasronilah, lalu kedua anak laki-laki tersebut keluar ke Syam bersama para pedagang tersebut, kemudia ayah dari dua anak laki-laki itu (Abu Husain) mendatangi rasulullah dengan mengadukan masalah kedua anak laki-laki nya, kemudian ayahnya menginginkan Rasulullah mengutus seseorang untuk mengajak kedua anaknya kembali lagi, kemudian Allah menurunkan ayat لا اكراه في الدين, seketika itu juga nabi tidak memerintahkan untuk memerangi ahlil kitab dan nabi berkata "Allah telah menjahui dua anak laki-laki tersebut dan dua anak laki-laki itu adalah orang yang pertama kali kufur" dan Abul Husain menemukan sendiri bahwa nabi Muhammad ketika nabi tidak mengutus seseorang untuk untuk mencari kedua anaknya. di 
فلا وربك لايؤمنون حتى tengah-tengah kejadian ini, Allah menurunkan wahyu atau ayat لا اكراه في surat an-Nisa' ayat 65. Kemudian ayat itu di nasekh oleh ayat يككوك فيا شجر بنيهم الدين

Tafsir surat al-Maidah ayat 5

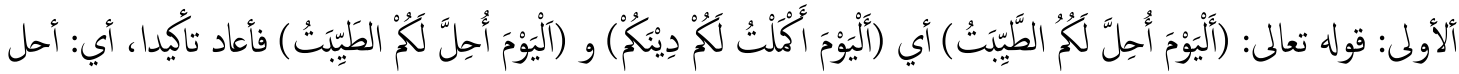

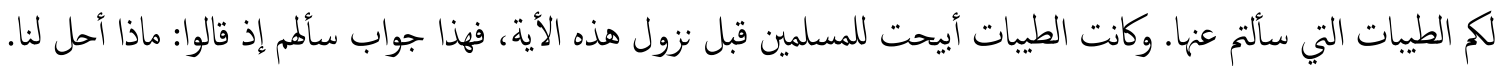

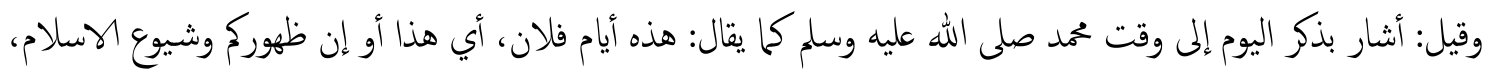

$$
\begin{aligned}
& \text { فقد أكملت بهذا دينكي، وأحللت لكم الطيبات، وقد تقدم ذكر الطيبات في الأية قبل هذا. }
\end{aligned}
$$

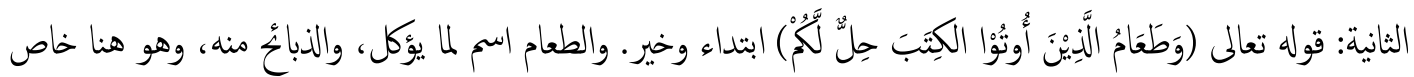

$$
\text { بالذباءُ عند كثير من أهل العلم بالتأويل. }
$$

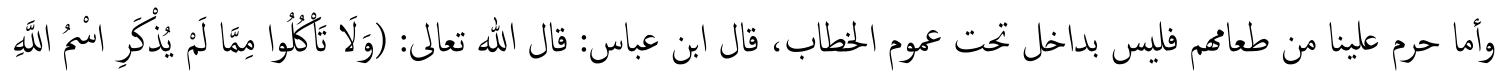

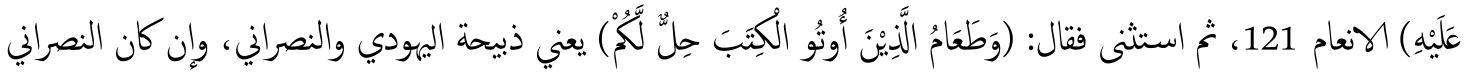
عند الذبح: باسم المسيح، واليهودي يقول : باسم عزير؛ وذلك لأهه يذبحون على المانلة.

قلت: العجب من الكيا الطبري الذي حكى الاتفاق على جواز ذبيحة أهل الكناب، ثم أخذ يستدل بذلك على أن التسمية على

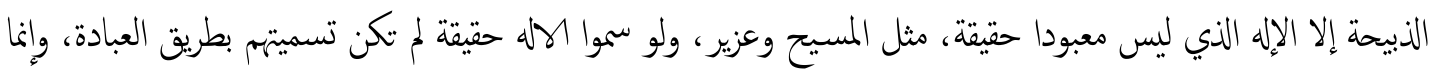

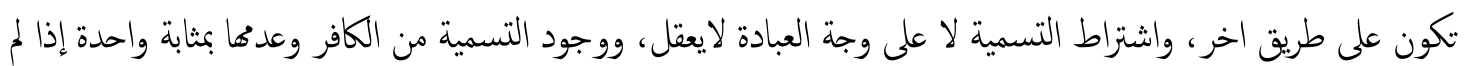

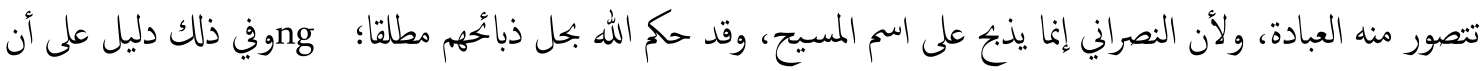

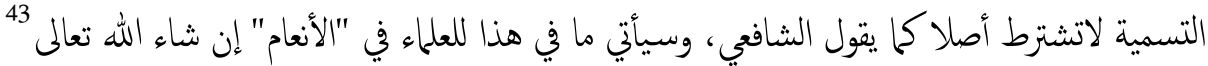

Sesungguhnya dalam tafsir ayat ini terdapat sepuluh masalah, akan tetapi dalam pemaknaan ini akan di jelaskan secara ringkas tentang beberapa masalah. Adapun beberapa masalah yang di ambil dari tafsir ayat ini adalah:

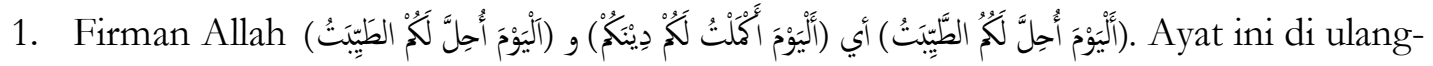
ulang sebagai tauqid atau penguat. Maksudnya saya (Allah) telah menghalalkan terhadap kalian segala sesuatu yang baik, sebelum turunnya ayat ini segala sesuatu yang baik itu di perbolehkan bagi ummat muslim, hal ini merupakan jawaban dari pertanyaan-pertanyaan mereka karena mereka berkata: apa yang di halalkan bagi kami?. Dan ada suatu pendapat: mengingat pada hari pada suatu waktu nabi Muhammad SAW memberi isyaroh sebagaimana yang di katakan " hari ini adalah harinya anak-anak" maksudnya sewaktu mereka menampakkan hal ini dan menyebarkan islam, maka sungguh saya telah menyempurnakan agama kalian, dan

42 Abi Abdillah Muhammad bin Ahmad bin Abi Bakar Al Qurtubi, Al Jami li Ahkam Al-quran, juz 7, hal 315

43 Ibid hal 316 
saya menghalalkan kepada kalian segala sesuatu yang baik. Ayat telah menjelaskan tentang Segala sesuatu yang baik di sebutkan terlebih dahulu sebelum kejadian ini.

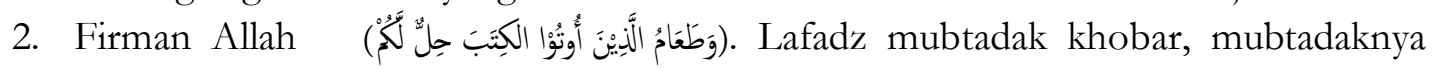

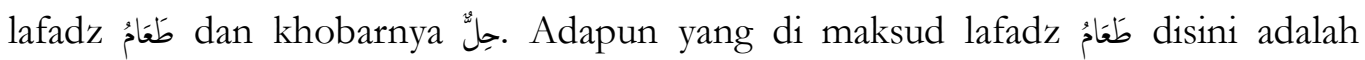
Perkara yang dapat di makan termasuk juga sembilihan-sembilahan bahkan dalam ayat ini di arahkan kepada sembelihan-sembelihan oleh para ulama di takwil jadi sembeliha-sembelihan para ahli kitab itu halal bagi kaum muslimin. Adapun makanan-makanan orang kafir ahli kitab yang di haramkan bagi kita, hal tersebut merupakan pebedaan konteks masalah atau tertuju pada pembahasan lain.

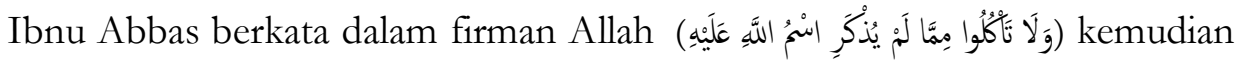

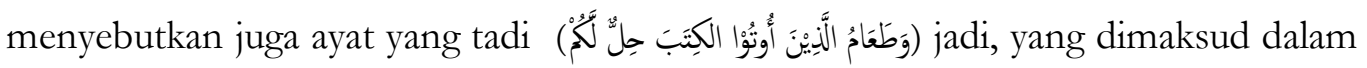
ayat itu adalah sembelihan orang-orang Yahudi atau Nasrani, walaupun Nasrani dalam menyembelih menyebut nama tuhannya (Al-Masih) dan orang Yahudi ketika menyembelih menyebut nama tuhannya juga (Uzair), karena mereka yang menyembelih atas nama agama, sehingga mereka menyebut nama tuhannya masingmasing.

Sedangkan pendapat dari pengarang kitab ini mengatakan, jadi yang termasuk pendapat yang menakjubbkan adalah Imam At-Thobari yang mengatakan bahwa ulama bersepakat tentang kebolehan memakan sembelihan ahli kitab dan beliau menyebutkan dalilnya yaitu "Bahwa membaca Bismillah dalam menyembelih itu bukan syarat syah atau halal" kemudian melanjutkan pembicaraannya, kita pasti tahu bahwa orang ahli kitab ketika menyembelih tidak mungkin menyebut nama Allah, andaikan mereka membaca Bismillah, jelas bukan merupakan ibadah pasti ada tujuan lain, karena mereka tidak pernah meyakini Allah. Jika bacaan Bismillah kemudian di jadikan syarat kepada orang ahli kitab, kemudian yang kita ketahui bahwa membaca Bismillah itu merupakan ibadah, ketika mereka mengatakannya maka hal demikian bukanlah ibadah dan tidak ma'kul. Dan dari penjelasan yang ada bisa kita ketahui bahwa ahli kitab Nasrani ketika menyembelih tidak mungkin menyebut Bismillah, namun menyebut tuhan mereka akan tetapi Allah menghalalkan sembelihan mereka. Dan membaca Bismilillah bukan persyaratan dalam menyembelih, sebagaimana yang telah di jelaskan oleh Imam Syafi'i bahwa, membaca Bismillah itu berhukum sunnah, meski Imam yang lain mewajibkannya, akan tetapi pada konteks ini akan di jelaskan secara rinci dalam surah al-An'am.

Tafsir Surat Al-Kafirun

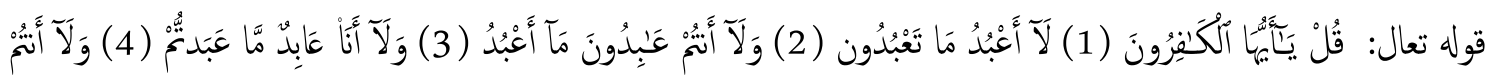

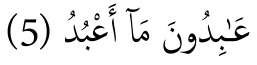

$$
\begin{aligned}
& \text { ذك ابن إسحاق وغيره عن ابن مسعود: أن سبب نزولها أن الوليد بن المغيرة، والعاص بن وائل، والأسود بن المطلب، وأمية بن }
\end{aligned}
$$

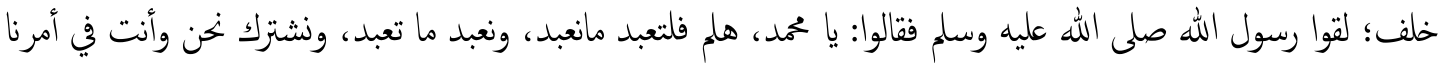




$$
\begin{aligned}
& \text { كله، فإن كان الذي جئت به خيرا ما بيدك، كنت قد شاركناك فيه، وأخذنا بحظنا منه وإن كان الذي بأيدنينا خيرا مما بيدك، }
\end{aligned}
$$

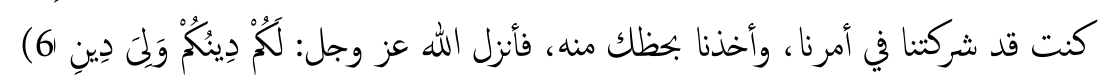

$$
\begin{aligned}
& \text { وقال أبو صالح عن ابن عباس : إنهم قالوا لرسول الله صلى الله عليه وسلم: لو استلمت بعض هذه الالهة لصدقناك، فنزل }
\end{aligned}
$$

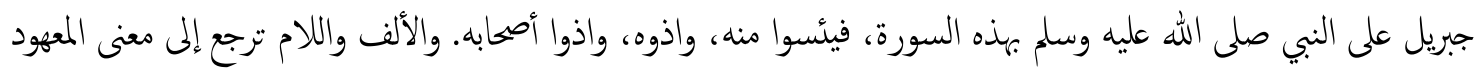

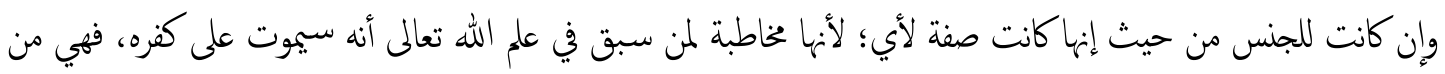

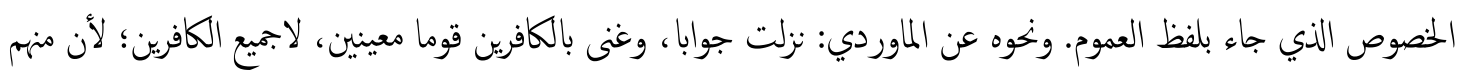

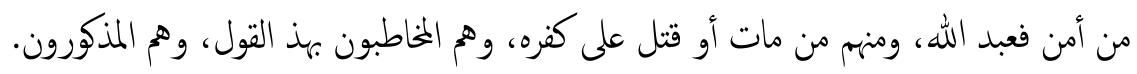

$$
\begin{aligned}
& \text { قال أبو بكر بن الأنباري: وقرأ من طعن في القرأن: (قُلْ لِلذين كفروا لاعبدما تعبدون) وزع أن ذلك هو الصواب، وذلك }
\end{aligned}
$$

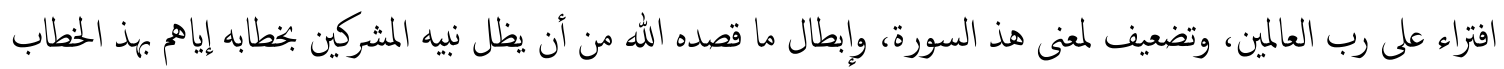

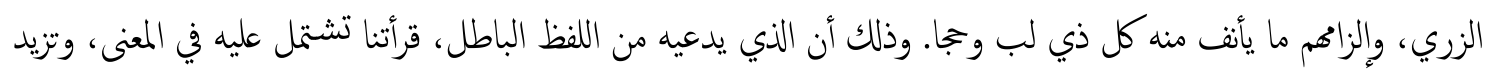

$$
\begin{aligned}
& \text { تأويلا ليس عندهم في باطلهم وتحريفهم فمعنى قراءتنا: قل للذين كفروا : ياأهيا الكافرون، دليل صحة هذا: أن أن العربي إذا قال }
\end{aligned}
$$

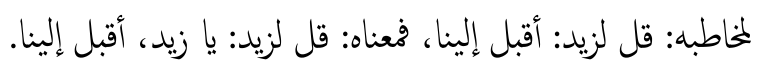

Dalam tafsir ini di jelaskan bahwa Imam Ibnu Ishak dan yang lain meriwayatkan dari Ibnu Abbas tentang turunnya surat Al-Kafirun ketika Walid bin Mughiroh bertemu dengan Rasulullah ia mengatakan, "Hai Muhammad mari kamu sembah apa yang kami sembah dan kami sembah apa yang kamu sembah kita lakukan bersama-sama dalam urusan ini, jika tuhan kamu itu lebih baik dari pada tuhan kami maka kami akan ikut serta menyembah tuhan kamu meskipun kami tetap menyembah tuhan kami, dan bila tuhan kami itu lebih baik dari pada tuhan kamu maka kamu harus ikut serta menyembah tuhan kami dan ibadah kami dan kamu juga di perbolehkan untuk menyembah dan beribadah dengan tuhan kamu.” Kemudian Allah menurunkan surat Al-Kafirun.

Kemudian di riwayatkan juga oleh Imam Abu Shaleh, diriwayatkan dari Ibnu Abbas. Bahwa yang di katakan oleh Walid bin Walid kepada Rasulullah bukanlah demikian, akan tetapi, mereka berkata kepada Rosulullah, "jika kamu menerima sebagian tuhan yang banyak ini maka kami akan mempercayai kamu" maka saat itu juga malaikat Jibril membawa surat Al-Kafirun. Sehingga mereka putus asa dan menyakiti nabi bahkan menyakiti sahabat-sahabat nabi. Kemudian alif lam pada surat Al-Kafirun memliki arti untuk kaum tertentu yang di tuju, meskipun secara lafadz menggunakan al-jinsiyyah yang menunjukkan makna umum, akan tetapi dalam konteks ini di maksud makna khusus. Dengan adanya bukti menjadi sifat dari lafadz ayyun. Karna di sini tentang mengucapkan sesuatu kepada objek orang-orang yang sudah Allah ketahui dalam ilmu Allah bahwa mereka akan mati dalam keadaan kafir. Jadi mereka merupakan kaum tertentu yang sudah Allah takdirkan untuk mati dalam keadaan kafir. Sehingga yang di kehendaki itu khusus, dalam arti, bukan semua orang kafir karena terdapat orang kafir yang sudah menganut agama Islam, namun yang di khususkan dalam ayat ini adalah orang kafir yang mati juga dalam keadaan kafir. 
Imam Abu Bakar al-Ambari mengatakan bahwa ada orang yang merusak Al-quran dengan merubah-rubahnya yaitu dengan mengatakan (قُلْ لِلنين كفروا لاعبدما تعبدون dan orang yang mengatakan atau merusak Al-quran, mereka merasa Al-quran itulah yang benar, sungguh apa yang dikatakan tadi mengada-ngada kepada firman Allah, untuk melemahkan makna surat Al-Kafirun dan merusak apa yang Allah tuju dengan turunnya surat itu, yaitu untuk menghina para musyrikin dengan surat ini yang berisi perkataan yang menghina mereka karena ada perbedaan makna dengan ayat surat yang Allah turunkan dengan ayat yang mereka rubah. Jadi sebenarnya tidak perlu di rubah kembali karena Allah menurunkan surat tersebut mencakup makna yang tadi telah di rubah. Karena walaupun ayat yang mereka rubah (قُلْ لِنين كفروا لاعبدما تعبدون) "katakan lah kepada mereka orang-orang kafir aku tidak akan menyembah apa yang kamu sembah" perkataan (kepada) seharusnya tidak di sebutkan dalam hal itu terbukti dalam kalam Arab ketika ada Arab mengatakan kepada orang di depannyalق قل لزيد: أقبل إلين

\section{Nilai Toleransi dalam Konteks Indonesia}

Dalam konteks Indonesia, Di tinjau dari segi budaya, sudah tidak lagi menjadi rahasia lagi bahwa Indonesia adalah negara yang memiliki kelimpahan aneka seni dan budaya dalam berbagai bentuknya. ${ }^{44}$ sedangkan di tinjau dari kenyataan sosial, bangsa Indonesia di huni oleh masyarakat multikurtural dan tentunya harus di junjung tinngi, dari hal inilah kemudian negara ini mendapatkan pengakuan bahwa dengan adanya keberagaman inilah bangsa Indonesia terwujud. ${ }^{45}$

Walaupun agama Islam merupakan agama moyoritas terbanyak penganutnya di Indonesia, dengan jumlah penganut kurang lebih mencapai $80 \%$, namun tidak menjadikan Islam sebagai agama negara. Semua agama yang terdapat di negara ini baik Islam, Kristen Protestan, Kristen Katolik, Budha, Hindu, Konghucu mendapat perlindungan yang sama oleh pemerintah dengan dasar negara pada Undang-undang Dasar 1945 pasal 29 yang mengatakan bahwa, "setiap warga negara berhak untuk memeluk agamanya masing-masing dan untuk beribadah menurut agamanya dan kepercayaannya". ${ }^{46}$

Indonesia adalah negara yang toleransi, namun mengingat agama sangatlah rentan maka membangun kehidupan umat beragama yang tentram dan harmonis bukan merupakan pekerjaan yang ringan. Dan tidak menutup kemungkinan akan terjadinya sebuah kesalah pahaman, walau telah terdapat Undang-undang yang di berlakukan. ${ }^{47}$ secara

\footnotetext{
${ }_{44}$ Nur Said, Meneguhkan Islam Harmoni Melalui Pendekatan Filologi, Fikrab: Jurnal Ilmu Aqidah dan Studi Keagamaan, Vol. 4 No. 2, 2016 hlm. 201

45 Muhatadin Dg. Musthofa, "Reorientasi Teologi Islam dalam Konteks Pluralisme Beragama "Telaah Kritis dengan Pendekatan Teologis Normatif, Dialogis dan Konvergensif”. Jurnal Hunafa Vol.3 No. 2 Juni 2006, hlm. 130

46 Yayan Sopyan, Menyoal Kebebasan Beragama dan Penodaan Agama di Indonesia. Jurnal Cita Hukum. Vol. II No.2 Desember 2015. ISSN: 2356-1440 hlm. 207

47 Studi Islamika "Babak baru keterangan Islam dan kristen di Indonesia". Editor In Chipe: Azyumardi Azra. Dkk. Indonesia Journal For Islamic Studies 2015. Vol.21 No. 3.
} 
umum di Indonesia masih rawan tejadi gesekan-gesekan konflik pada Masayarakat, khususnya terkait tentang penyiaran atau penyebaran agama, pembangunan tempat ibadah, kegiatan aliran sempalan, penodaan agama, dan lainnya. ${ }^{48}$

Salah satu konflik yang terjadi di Indonesia sebagaimana Rumadi ( Wahid Institute) mencatat, 232 kasus pelanggaran HAM, baik dari kekerasan berbasis agama, penyesatan agama, serta pembatasan kebebasan berekspresi, hal ini merupakan suatu tantangan yang harus di hadapi oleh Negara. ${ }^{49}$

Dalam tafsir Al- qurthubi Imam At-Thobari yang mengatakan bahwa ulama bersepakat tentang kebolehan memakan sembelihan dari agama selain dari Islam, hal ini menerangkan bahwa umat islam di persilahkan menerima hidangan dari agama lain selama hidangan tersebut bukan sesuatu yang haram.

Dalam Al-quran Allah menurunkan ayat لا اكراه في الدين Tidak ada paksaan untuk memasuki agama Islam, Kemudian sebagaimana dalam kitab Al-qhurtubi, Allah menurunkan surat Al-Kafirun sebagai ayat yang yang menjelaskan tentang hakikat toleransi dalam menerima perbedaan dan berkomitmen terhadap agama yang di pilhnya, maksud dari ayat-ayat ini menjelaskan, bahwa ummat Islam tidak melarang untuk menerapkan sikap saling berhubungan baik kepada agama lainnya, seperti yang telah di terapkan di Indonesia dalam semboyan yang kokoh yaitu "Bhineka Tunggal Ika".

Dari segi penerapan, Negara Indonesia merupakan negara yang sesuai dengan yang tercantum dalam Al-quran khususnya pada ayat-ayat toleransi, sebagaimana tafsir dalam surah Al-Kafirun, dan beberapa ayat $\mathrm{Al}$-quran yang secara jelas menjelaskan tentang dasardasar bertoleransi, akan tetapi menjadi yang wajar jika terjadi gesekan konflik pada Masyarakat.

\section{Penutup}

Istilah Toleransi Dalam bahasa Arab kata yang serupa dengan makna toleransi adalah Ikhtimal dan Tasammuh, yang memiliki makna sikap membiarkan, teposelero dan lapang dada. Menurut ajaran agama Islam, toleransi bukan saja di realisasikan terhadap sesama manusia, akan tetapi juga terhadap ciptaan tuhan yang lainnya,baik terhadap lingkungan hidup, Alam semesta, dan binatang. manifestasi toleransi beragama diartikan suatu sikap kelompok yang menerima adanya perbedaan yang timbul dari seorang yang berkeyakinan kepada agama berbeda. Melalui adanya proses menghormati, dan menerima atas adanya keyakinan yang berbeda-beda. Menurut dasar Islam berarti mempunyai konsep yang jelas, tidak ada pemaksaan dalam melilih agama, contoh landasan yang nyata dalam Al-

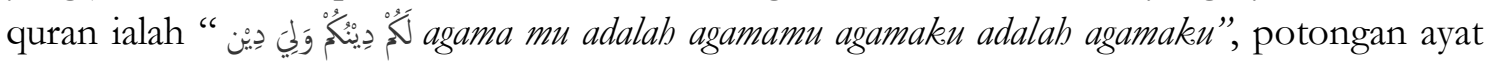
ini adalah salah satu contoh populer pada konteks toleransi bagi agama Islam di sinilah

${ }^{48}$ Muhaimin AG, Damai di dunia untuk. semua perspektif bebagai agama (Jakarta: Puslitbang, 2004), Hlm.19

${ }^{49}$ M. Zainuddin, Kebebasan Beragama dan Demokratis di Indonesia, el-Harakah, Vol. 11, No2, Tahun 2009. hlm. 177 
letak dasar Islam mengenai toleransi bergama. Dalam kitab Al-qhurthubi, ayat ayat toleransi memiliki banyak pendapat tentang toleransi. Di Indonesia adalah negara yang toleransi, namun mengingat agama sangatlah rentan maka membangun kehidupan umat beragama yang tentram dan harmonis bukan merupakan pekerjaan yang ringan. Dan tidak menutup kemungkinan akan terjadinya sebuah kesalah pahaman, walau telah terdapat Undangundang yang di berlakukan. Secara umum di Indonesia masih rawan terjadi konflik pada Masayarakat, khususnya terkait tentang penyiaran atau penyebaran agama, pembangunan tempat ibadah, kegiatan aliran sempalan, penodaan agama, dan lainnya.

\section{Daftar Pustaka}

Adi, Suroso, Menejemen Alam: Sumber Pendidikan Nilai, Bandung: Mughni Sejahtera, 2006.

AG, Muhaimin, Damai di dunia untuk semua perspektif berbagai agama, Jakarta: Puslitbang, 2004.

Bakar, Abu, "Konsep Toleransi dan Kebebasan Beragama", Toleransi: Media Komonikasi Umat Beragama, Vol. 17, No. 2 Juli-Desember 2015.

Casram, Membangun Sikap Toleransi Beragama Dalam Masyarakat Plural, Jurnal: Wawasan jurnal Ilmiah Agama dan Sosial budaya 1, 2.187-198 juli 2016.

Hakim, Atang Abd. Metodologi Studi Islam, Bandung: Pustaka Setia, 2008.

Huda, M Thoriqul,'Toleransi dalam Kitab Tafsir Taisir al-Karim al-Rahman fi Tafsir alKalam al-Mannan", Qolamuna; Jurnal Studi Islam, Vol. 4 No, 2019.

Huda, M Thoriqul,'Urgensi Toleransi Antar Agama dalam Prespektif Tafsir al-Sya'rawi", Tarbiya Islamia: Jurnal Pendidikan dan Keislaman, Vol 8 No. 12019.

Huda, M Thoriqul dan Nur Hidayati,"Peran Komisi Hubungan Antar Umat Beragama Gereja Katolik dalam Membangun Dialog", Religi; Jurnal Studi Agama-Agama, Vol 14 No. 22019.

Husaini, Adian, Hermeneutika dan Tafsir Al-quran Jakarta: Gema insani, 2007.

Khadijah, "Toleransi Beragama Dan Amalannya di Malaysia” Jurnal Ushuluddin, Bil 272008.

Ma'arif, Ahmad Syafi'i, Membumikan Islam, Yogyakarta: Pustaka Pelajar, 1950.

Mustafa, Mujetaba, "Toleransi Beragama dalam Perspektif Al-quran" TASAMUH Vol. 7, No.1, April 2015,

Muhatadin Dg. Musthofa, "Reorientasi Teologi Islam dalam Konteks Pluralisme Beragama "Telaah Kritis dengan Pendekatan Teologis Normatif, Dialogis dan Konvergensif'. Jurnal Hunafa Vol.3 No. 2 Juni 2006.

Naim, Ngainun, Islam Dan Pluralisme Agama Dinamika Perebutan Makna Yogyakarta:Aura Pustaka,2014.

Ridho Dinata, Muhammad, "Konsep Toleransi Beragama", ESENSLA Vol. XIII No.1 Januari 2012,.

Salman, Abdul Malik, al-Tasamub Tijah al-Aqoliyyat ka Dharuratin li al-Nabdhah, Kairo: The International Instutite Of Islamic Thought, 1993.

Said, Nur, Meneguhkan Islam Harmoni Melalui Pendekatan Filologi, Fikrab: Jurnal Ilmu Aqidah dan Studi Keagamaan,

Shihab, Alwi, Islam Inklusif, Menuju Sikap Terbuka dalam Beragama, Bandung: Mizan, 1997. 
Shihab, M.Quraisy, Membumikan Alquran Fungsi dan Pesan Wabyu Dalam Kebidupan Masyarakat, Bandung: Mizan, 1992.

Shihab, M.Quraisy.Tafsir Al-Misbah, Pesan, Kesan dan Keserasian Al-quran, Jakarta: Lentera hati, Vol I,

Sopyan, Yayan, Menyoal Kebebasan Beragama dan Penodaan Agama di Indonesia. Jurnal Cita Hukum. Vol. II No.2 Desember 2015. ISSN: 2356-1440.

Studi Islamika "Babak baru keterangan Islam dan kristen di Indonesia". Editor In Chipe: Azyumardi Azra. Dkk. Indonesia Journal For Islamic Studies 2015. Vol.21 No. 3.

Syaefullah, Asep, Merukunkan Umat Beragama (studi pemikiran tarmidzi taher Tentang Kerukunan Umat bergama), Jakarta Selatan: Grafindo Khasanah Ilmu, 2007.

Suryana, Toto. "Konsep dan Aktulisasi Kerukunan Ummat Beragama". Jurnal Pendidikan Agama Islam - Ta’lim Vol. 9 No. 2 - 2011.

Yasir, Muhammad. "Makna Toleransi Dalam Al-quran" Jurnal Ushuluddin Vol.XXI No.2,Juli 2014.

Zainuddin M, Kebebasan Beragama dan Demokratis di Indonesia, el-Harakah, Vol. 11, No2, Tahun 2009. 